\title{
Sisprenatal As an Evaluation Instrument of the Pregnant Woman Care in the Strategy Family Health

Ericka Silva Holmes ${ }^{1}$, Sérgio Ribeiro Dos Santos ${ }^{2}$, Leila de Cássia Tavares da Fonsêca², Maria Bernadete de Sousa Costa ${ }^{2}$, Gyl Dayara Alves de Carvalho ${ }^{3}$, Saemmy Grasiely Estrela de Albuquerque ${ }^{3}$, Julianne Cristinne Ferreira de Sousa ${ }^{4}$, Deborah Rayanne Roseno de Jesus ${ }^{5}$, Emília Maria Pacheco André ${ }^{6}$, Sílvia Virginia Pereira da Silva7, Rossana de Araújo Barboza ${ }^{8}$, Camila Karla da Cunha Gonçalves Branco Falcão9 Analine de Souza Bandeira Correia ${ }^{10}$, Nayara Alves de Oliveira9, Renata Michelle dos Santos Barreto ${ }^{11}$, Maria Betânia Lacerda ${ }^{6}$, Ana Priscylla Medeiros de Alencar Simão ${ }^{12}$

\section{Abstract}

Introduction: Prenatal care comprises a set of care aimed at preserving the health of pregnant women and the fetus, intervening at an early stage in risk situations. The SISPRENATAL was created to over see the actions scheduled for PHPN and facilitate the transfer of funds. However, the high rates of maternal and neonatal morbidity and mortality are still a challenge to public health.

Objective: Investigating, in national literature, the use of SISPRENATAL in assessing the health care of pregnant women in the Family Health Strategy.

Method: Integrative systematic, which seeks to answer $<$ How SISPRENATAL used to assess the health care of pregnant women in the ESF under the existing publications? >> The search was conducted in the databases SciELO, LILACS and BDENF, using the descriptors: women's health, information systems, prenatal care and the key Word SISPRENATAL. For the analysis of the articles sought to the units of meaning that make up the corpus of 10 selected articles.
1 Nurse. Master's Program Graduate Program in Health and Decision Models at the Federal University of Paraíba (PPGMDS / UFPB). *JP-PB.

2 Department of Clinical Nursing at the Federal University of Paraíba (DENC) UFPB). *JP-PB.

3 Nurse. Master's Graduate Program in Nursing at the Federal University of Paraíba (PPGEnf/UFPB). *JP-PB.

4 Nurse. Resident in nephrology of integral medicine Institute Ms. Fernando Figueira (IMIP/PE). Recife-PE, Brazil.

5 Nurse. Specializing in Intensive Care Unit for Improvement Center and Research (CEFAPP). *JP-PB.

6 Nurse. Specialist in the Women's health. *JP-PB.

7 Nurse. Multidisciplinary Residency in Child Health. *JP-PB.

8 Nurse. Primary Health Care Coordinator in Macaparana-PE. Brazil.

9 Nurse. Graduate at the Federal University of Paraíba. *JP-PB.

10 Nurse. Multiprofessional residence in Mental Health. *JP-PB.

11 Nurse. Residing in Nursing Scrubs of integral medicine Institute Ms. Fernando Figueira (IMIP/PE). Recife-PE, Brazil.

12 Nurse. Graduate from the Faculty Maurice of Nassau. *JP-PB. *JP-PB = João Pessoa-PB, Brazil

\section{Contact information:}

Ericka Silva Holmes

” ericka_holmes@hotmail.com 
Results: Highlight was the publication of a small number of studies, however, consider all the SIIPRENATAL an important health information tool.

Conclusion: SisprenatAL has many weaknesses in their use, which must be overcome to ensure improvements in the quality of maternal and perinatal care.

\section{Keywords}

Women's Health; Information Systems; Prenatal Care; Pregnancy; Humanization of Assistance.

\section{Introduction}

In the last years, improvements in women's health conditions, particularly in developed countries, have been observed. However, in developing countries like Brazil, there are many problems related to reproductive health, highlighting the risk of maternal death from pregnancy, childbirth or puerperium. [1]

The analysis of maternal health situation in Brazil presents serious epidemiological situation starred by women and their neonates, victims of the fragility of care provided to the population. This is due to the fact that at birth is privileged to the technology and the medicalized practice, depersonalized and interventionist, where cesarean rates are very high and the maternal mortality rates are alarming. [2]

In opposition to this idea, the prenatal care comprises a set of care and procedures that aim to preserve pregnant women's health and fetus, ensuring the prophylaxis and early detection of own pregnancy complications and proper treatment of pre-existing maternal diseases. It should also include guidelines about healthy lifestyle and changes resulted from pregnancy as well as preparation of the pregnant woman for childbirth and puerperium. [3] Thus, prenatal care aims to ensure maternal and embryonic/fetal health during the whole pregnancy and in the birthing process. [4]

Moreover, adequate prenatal care, early detection and intervention of risk situations, as well as an agile system of hospital reference (obstetric beds regulation, plan to bind pregnant woman to motherhood), qualification of childbirth care (humanization, pregnant woman's right to choose her own companion, ambience, good practices, host with risk classification), are great determinants of health indicators related to the mother and her baby that have potential to decrease the main causes of maternal and neonatal mortality. [5]

In this sense, ensuring the development of the gestation, allowing the birth of a healthy newborn without impact to the maternal health, including addressing psychosocial aspects and educational and preventive activities are some of the main objectives of prenatal monitoring. Therefore, early prenatal care initiation is essential for proper assistance. [6]

The World Health Organization (WHO) recommends at least six visits as appropriate number for prenatal care, which visits must be monthly done until the $28^{\text {th }}$ week, fortnightly between $28^{\text {th }}$ and $36^{\text {th }}$ weeks and weekly at the end, without prenatal discharge. [5] Yet, a prenatal care and a qualified and humanized puerperal happen through incorporating cozy behaviors and without unnecessary interventions; easy access to quality health services with actions that integrate all attention levels: promotion, prevention and assistance to the health of the mother and the newborn, from the basic ambulatory care to the hospital care for high risk. [6]

Therefore, in 2000 was deployed throughout Brazil the Program for Humanization of Prenatal 
and Childbirth Care (Programa de Humanização do Pré-Natal e do Nascimento- PHPN) by Ministry of Health (MS), after several years of Integrated Assistance Program for Women's Health (Programa de Assistência Integral à Saúde da Mulher-PAISM). This program established quantitative parameters for minimal care being offered to women, from basic care to the highest levels of complexity, an unprecedented manner in the country. [7] This program also emphasized women's rights affirmation, proposing humanization as a strategy for improving care quality, as well as maternal mortality reduction, aiming to ensure pregnant women's rights to access and a worthy quality care during pregnancy/childbirth and puerperium. [8]

For financial resources transfer provided by PHPN, it was made possible the Electronic System for Information Collection on Prenatal Monitoring of pregnant women attended by SUS (Sistema Eletrônico para a Coleta de Informações sobre o Acompanhamento Pré-natal das gestantes atendidas pelo SUS), the SISPRENATAL, which passed to be fed systematically with data service from pregnant women care, once this transfer depended on minimum requirements as early prenatal care initiation, at least six visits, immunization against tetanus, two basic exams routines (including serology for HIV and syphilis) and puerperal consultation until 42 days. [7-9]

SISPRENATAL serves to generate information concerning the aspects of prenatal care management and monitoring of the fulfillment with the minimum necessary actions contemplated in the program at any level of complexity of the health system, influencing in the decision-making, with regard the definition of interventions in pregnancy care process. For this, the Registration Form of Pregnant Woman and Registration Card Daily Attendance were used as two data sources. They were completed by professionals who performed the first appointment and the following ones. [4]

This system aims to get health information during prenatal, childbirth and puerperium, which is a key action for evaluation of care in different contexts. The information obtained, if they are really accurate, may reflect the panorama of maternal health in Brazil, allowing investments in local, regional and national levels, with specifications for each population group or social context. However, nearly a decade of implementation of PHPN, different studies show that its coverage is still much lower than expected, showing high rates of maternal mortality in the country. $[7,4]$

Thereby, considering that the high maternal morbidity and mortality rates remain a challenge to be overcome in Brazil and given importance of ensuring quality care to women throughout pregnancy, childbirth and puerperium. It is considered important to conduct this study that has as goal to conduct a systematic review of the literature on the use of SISPRENATAL in evaluating the health care of pregnant women in the ESF.

\section{Method}

This study is a type systematic literature review that seeks to answer the following questioning $<<$ How is the SISPRENATAL used to evaluate the health care of pregnant women in the ESF according to existing publications? $>$, which is a form of research using literature as a data source, obtaining them by means of a strategy for intervention, applying explicit and systematic search methods, to identify themes that require new investigation, as well as the synthesis of information about particular theme. [10]

This study was accomplished by following seven steps based on the Cochrane Handbook, enumerated as: 1- scientific question formulation, 2- location and selection of the studies, 3- critical evaluation of the studies, 4- data collect, 5- data analysis and presentation, 6- data interpretation, 7- review improvement and updating. [11]

Systematic review included the participation of two researchers who evaluated the methodologi- 
cal quality of each article independently, through the creation of a research protocol including from the places of search, inclusion and exclusion criteria, definition of outcomes of interest, until the results analysis.

As regard to the search performed in virtual libraries, it was involved national scientific productions published in online periodicals from 2000 to September 2014, based on the year of program creation, where articles concerning the SISPRENATAL usage for evaluating health care of pregnant woman were selected. The Virtual Health Library (Biblioteca Virtual em Saúde-BVS), that used the database from Latin American and Caribbean Literature in Health Sciences (Literatura Latino-Americana e do Caribe em Ciências da Saúde-LILACS), and the Nursing Database (Base de Dados em Enfermagem-BDENF); and the Scientific Electronic Library Online (SCIELO) were used for this.

The collect of periodicals was conducted in September and October 2014. The following descriptors, in English and Portuguese, were used in this periodicals research: "Saúde da Mulher/Women's Health; Sistema de Informação/Information Systems; Cuidado Pré-natal/Prenatal Care", interspersed with the Boolean operator "AND"; and the key word "SISPRENATAL" with which were done all possible combinations.

For filtering and sample selection from the periodicals, it was established as selection criteria: full-text articles, available and free, "free full text", published from 2000 to October 2014 in Portuguese. Articles in duplicate, in other languages, dissertations and theses, other systematic reviews beyond those studies that did not address directly the issue in focus were excluded. (Figure 1)

It was built and used an instrument with the following features to accomplish the analysis of the manuscripts found: article title, publication year, database where it was published, regional location of the realization of the study, type of study, professional qualification from the main author, institution,

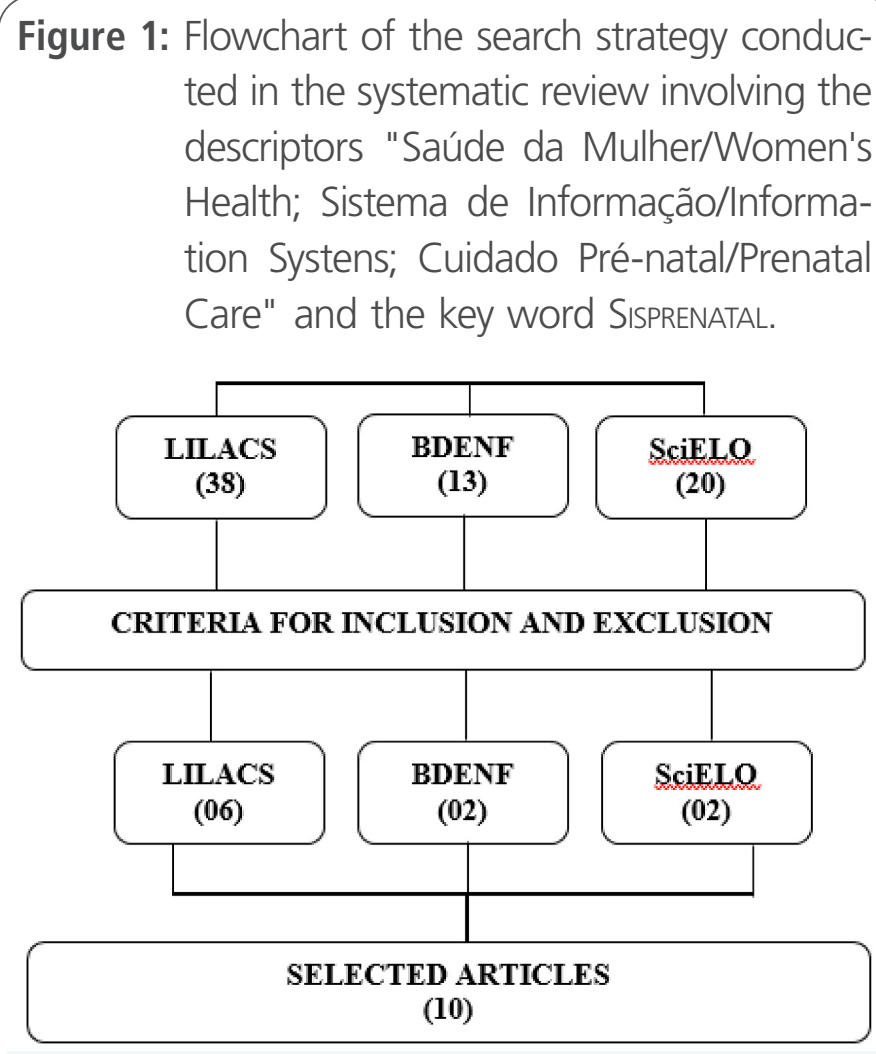

Source: Direct Research, 2014

objectives, results and conclusions. Then, the data were tabulated in an electronic spreadsheet.

This content analysis was developed in a systematic and critical way as it was conducted an in-depth reading of the articles found. Because it was a study of systematic review, it was dispensed to submission of the research project to Platform Brazil for trial at the Research Ethics Committee-CEP.

\section{Results}

Those results were found from the 10 articles that composed the study sample. It is noteworthy that most part of the articles were found in three database simultaneously, being considered, so, the search order as described previously.

According to Table 1, it is observed that most of the articles found are available in LILACS 6 database, followed by BDENF and SciELO with two publications in each one; and about the publication years, it can be noticed that they were in equal 
Table 1. Characterization of the 10 items selected in the systematic review as to the authors, publication year, study place, database and the study title.

\begin{tabular}{|c|c|c|c|c|c|}
\hline $\mathbf{N}^{\circ}$ & Authors & $\begin{array}{l}\text { Publication } \\
\text { Year }\end{array}$ & $\begin{array}{l}\text { Study } \\
\text { Place }\end{array}$ & Database & Study Title \\
\hline 1 & $\begin{array}{l}\text { Corrêa, Arantes, } \\
\text { Lima, et al }\end{array}$ & 2013 & $\begin{array}{l}\text { Cuiabá-Mato } \\
\text { Grosso }\end{array}$ & LILACS & $\begin{array}{l}\text { Analysis of prenatal care in the city of Cuiabá Mato } \\
\text { Grosso according to the data of SISPRENATAL }\end{array}$ \\
\hline 2 & Lima e Corrêa & 2013 & $\begin{array}{l}\text { Cuiabá-Mato } \\
\text { Grosso }\end{array}$ & LILACS & $\begin{array}{l}\text { The production data to the information system of } \\
\text { prenatal care at basic health units }\end{array}$ \\
\hline 3 & Lima e Corrêa & 2012 & $\begin{array}{l}\text { Cuiabá-Mato } \\
\text { Grosso }\end{array}$ & LILACS & $\begin{array}{l}\text { The production of data and information to the } \\
\text { SISPRENATAL at the central level management }\end{array}$ \\
\hline 4 & Soares, Bento, Silva & 2012 & Tanque-Piauí & LILACS & $\begin{array}{l}\text { Diagnosis of maternal and child health situation in } \\
\text { the city of Tanque do Piauí-PI }\end{array}$ \\
\hline 5 & $\begin{array}{l}\text { Andreucci, Cecatti, } \\
\text { Macchetti, et al }\end{array}$ & 2011 & $\begin{array}{l}\text { Campinas-São } \\
\text { Paulo }\end{array}$ & LILACS & $\begin{array}{l}\text { SISPRENATAL as an instrument of evaluation of the } \\
\text { quality of care for pregnant women }\end{array}$ \\
\hline 6 & $\begin{array}{l}\text { Pitombeira, Teles, } \\
\text { Paiva, et al }\end{array}$ & 2010 & $\begin{array}{l}\text { São Gonçalo do } \\
\text { Amarante-Ceará }\end{array}$ & BDENF & Prenatal care in the context of family health strategy \\
\hline 7 & $\begin{array}{l}\text { Gangreiro, } \\
\text { Diógenes, Moura }\end{array}$ & 2008 & Quixadá-Ceará & BDENF & $\begin{array}{l}\text { Prenatal care in the city of Quixadá-CE according to } \\
\text { the process indicators of SISPRENATAL }\end{array}$ \\
\hline 8 & $\begin{array}{l}\text { Nascimento, Paiva, } \\
\text { Rodrigues }\end{array}$ & 2007 & Salvador-Bahia & LILACS & $\begin{array}{l}\text { Evaluation of the coverage and indicators of the } \\
\text { humanization program of prenatal and birth in the } \\
\text { city of Salvador, Bahia, Brazil }\end{array}$ \\
\hline 9 & $\begin{array}{l}\text { Serruya, Lago, } \\
\quad \text { Cecatti }\end{array}$ & 2004 & Brasil & SCIELO & $\begin{array}{l}\text { Preliminary evaluation of the humanization program } \\
\text { in prenatal and birth in Brazil }\end{array}$ \\
\hline 10 & $\begin{array}{l}\text { Serruya, Cecatti, } \\
\text { Lago }\end{array}$ & 2004 & Brasil & SCIELO & $\begin{array}{l}\text { Humanization program in prenatal and birth from } \\
\text { Ministry of Health in Brazil: initial results }\end{array}$ \\
\hline
\end{tabular}

Source: Direct Research, 2014

amounts in 2004, with a jump to the years of 2012 and 2013 with two publications each year. Moreover, it is observed that the region that had the highest number of studies was the city of CuiabáMato Grosso.

To structure the results better, the studies were divided into two thematic categories, namely: CT-1.
Utilization of SISPRENATAL as an evaluation tool to the health of pregnant woman; and CT-2. The SISPRENATAL as a means of generating data and evaluating of the PHPN; the division made by these categories can be viewed in Table 2 .

Table 2. Division of 10 articles on thematic categories and presentation of their objectives.

\begin{tabular}{|c|c|c|}
\hline $\begin{array}{l}\text { Thematic } \\
\text { Categories }\end{array}$ & $\begin{array}{l}\text { Article } \\
\text { Number }\end{array}$ & Objectives of each Study \\
\hline \multirow{5}{*}{$\begin{array}{l}\text { CT - } 1 . \\
\text { Utilization } \\
\text { of the } \\
\text { SISPRENATAL } \\
\text { as an } \\
\text { evaluation } \\
\text { tool to the } \\
\text { health of } \\
\text { pregnant } \\
\text { woman }\end{array}$} & 1 & Analyzing the prenatal care in Cuiabá from sISPRENATAL 2010 data. \\
\hline & 4 & Describing the diagnosis of maternal and child health in the city of Tanque do Piauí PI. \\
\hline & 5 & $\begin{array}{l}\text { Evaluating the coverage of the humanization program of prenatal and birth according to the } \\
\text { compliance with its minimum requirements and process indicators, comparing the pregnant } \\
\text { woman's card information with the ones from SISPRENATAL. }\end{array}$ \\
\hline & 6 & Studing the prenatal care offered in the city of São Gonçalo do Amarante based on the information. \\
\hline & 7 & $\begin{array}{l}\text { Analisar os indicadores de processo do Sistema de Analyzing Information System process indicators } \\
\text { of the Prenatal (SISPRENATAL) in Quixadá-CE. }\end{array}$ \\
\hline
\end{tabular}




\begin{tabular}{|c|c|c|}
\hline $\begin{array}{l}\text { Thematic } \\
\text { Categories }\end{array}$ & $\begin{array}{l}\text { Article } \\
\text { Number }\end{array}$ & Objectives of each Study \\
\hline \multirow{5}{*}{$\begin{array}{l}\text { CT }-2 \text {. The } \\
\text { SISPRENATAL as } \\
\text { a means of } \\
\text { generating } \\
\text { data and } \\
\text { evaluating of } \\
\text { the PHPN }\end{array}$} & 2 & Analyzing the data production process for sISPRENATAL in Basic Health Units of Cuiabá, MT, Brazil. \\
\hline & 3 & $\begin{array}{l}\text { Analyzing the data production process and information for SISPRENATAL at the central level } \\
\text { management of Cuiaba - MT. }\end{array}$ \\
\hline & 8 & $\begin{array}{l}\text { Calculating some process indicators for prenatal care provided to pregnant women in public services } \\
\text { in Salvador, Bahia. }\end{array}$ \\
\hline & 9 & $\begin{array}{l}\text { Evaluating the implementation experience of the Humanization Program in Prenatal and Birth } \\
\text { (PHPN) in Brazil, through a descriptive and populational study, with information from the years of } \\
2001 \text { and } 2002 \text {. }\end{array}$ \\
\hline & 10 & $\begin{array}{l}\text { Evaluating the implementation experience of the Humanization Program in Prenatal and Birth from } \\
\text { the Brazilian Ministry of Health, according to the data generated by SISPRENATAL/DATASUS. }\end{array}$ \\
\hline
\end{tabular}

\section{Discussion}

\section{CT - 1. Sisprenatal as a management tool for evaluation of maternal health}

The articles that composed the sample of this study and belong to this category, revealed the utilization of Sisprenatal as a tool of the process of evaluation of woman care quality during prenatal, being evidenced in various realities how much is underutilized by professionals. In a study conducted in Cuiabá was detected that the Sisprenatal has generated elements that favor management for the care of pregnant women, on the other hand, the existence of failures in handling and operating the system have revealed the need to invest in improving it. [4]

It is known that prenatal care quality is an important strategy in reducing maternal and perinatal mortality, in view of many pathologies that occur in this period can be diagnosed and treated early, preventing complications for the mother and her child, therefore, this monitoring has been evaluated through the records in the SISPRENATAL. [12]

In this perspective and evaluating the articles found, it was observed that in one of the studies that sought to compare the data about the prenatal care at the pregnant woman's card and SISPRENATAL, obtained as result a large disparity among the re- cords, highlighting the existence of underreporting of procedures in the system about what effectively had been performed and documented in the prenatal card. Moreover, PHPN process indicators allow quantitative assessments, where the proportion of pregnant women who meet the minimum suggested can be determined, but the quality of care can not be evaluated by the same indices, therefore, should be reassessed. [13]

Another study verified that most professionals do not recognize the importance of recording of data on prenatal care, which neglect the filling of some fields relating to codes on the forms of SISPRENATAL, and this deficiency is related to the care failure that exists in health services making the postpartum return to the health unit for monitoring, compromising the records that should be performed.

Corroborating this perspective, a survey conducted in the city of Quixadá-EC, also detected a reduction in the registration of pregnant women, which are caused by the initial period of the implantation of SISPRENATAL, as well as arising from operational failures of responsibility of professionals of the assistance and the feeding of themselves. [3]

In compensation, a study that used the SISPRENATAL data to conduct an assessment regarding the health status of maternal and child population, detected that the information contained in SISPRENATAL 
and in other systems are extremely important both for epidemiological character and for subsidizing the organization and programming of health actions of a community, where professionals working in the ESF can develop and implement programs for the quality of care provided, from the available data. [2]

In general, it is observed that the PHPN has many challenges represented by the need for constant stimulation to adhesion and maintenance of the program in each city; by a more effective availability of health information, with the creation of strategies to avoid data loss; and also for investments for the initial proposal fulfillment which includes the humanization of attendance. It is important to ensure that pregnant women feel welcomed by the health network. [2]

Thus, attitudes and humanized actions developed by managers and health workers are needed to improve the quality of obstetric and neonatal care, in which the correct use of the available information will allow nationwide programs to be developed with awareness of local and regional differences, ensuring a better resoluteness to the national public health. [13]

\section{CT - 2. SisprenAtAl as a means of data production and evaluation of PHPN}

The development of the information system about prenatal provided reports and indicators and drew a disturbing and challenging picture of the maternal care, indicated by low percentages registered. However, a comparison of service quality indicators, appointed by SISPRENATAL revealed a growth only at the beginning of its implementation in the years of 2001 and 2002. [14]

Research conducted on the preliminary assessment of PHPN found that based on the evaluation of the set of the program indicators was possible to observe that there was an increase in all indicators, beginning the coverage that grew significantly in $70 \%$ of the women registered in 2002 .
However, it is highlighted a decrease of these percentages related, above all, to the maintenance of the set of activities, which is the biggest challenge. Moreover, it was possible to understand that where the organization and management of services are more established, coincidentally with the economic and social development, showed better results, opposing in this way the realities of the regions where there are scarcity of resources. [15]

More specifically, in the city of Salvador-BA, in 2002 only $37.2 \%$ of the units had implemented the program, pointing, thereby, to the difficulties of access of women to health services, to laboratory tests, diagnostic and specialized complementation, going against what has been put by the studies cited above. This low percentage of pregnant women enrolled in the PHPN can be explained by the existing deficiency in the offering of health services in terms of quantity and quality, in addition to problems related to the early identification of pregnant women. [16]

Other problems are also related to the use of the system, starting with the lack of knowledge of its own managers that work in the management of the primary care, which their works are only directed to the collection of practices carried out by other professionals and the achievement of goals. One problem mentioned by the typist is closely linked to the writing of the professional that fills the forms is unreadable. In addition to these difficulties, it is reported flaws in the software as the lack of inappropriate processing capacity of the system that triggers slowness in the work processes, because of the service overload and breakdowns that prevent its proper use. [17]

In a study conducted in the city of Cuiabá, it was reported that most professionals do not recognize the importance that the data registration about the prenatal care and postpartum needs to be done by the professional who actually collected them, so that the information generated are reliable. $[9,17]$ 
The data presented in this study share the same results found in another systematic review, which deals with the performance of program indicators. In this study it was observed that comparing the constant official information in the system and information from other sources such as medical records, it is noted that the fulfillment of the goals and process indicators seem to be underreported in the information system. In this way and following this reasoning, the data documentation is probably deficient in a national level, not reflecting the real monitoring of pregnant women in the different health networks in the country, which constitutes in a big problem. [7]

In this context, knowing the rates and health indicators through PHPN, we can facilitate the links between the programs Health of Woman, Children and Adolescents and the ESF in an attempt to qualify the care to the parturition and birth, supporting social actions that give support to pregnant women and newborns at risk.

However, health professionals need to get qualified through courses and training, through actions related to the permanent health education, considering that the humanization, welcoming, and clinical management during parturition should be studied and improved, as well as an epidemiological investigation and the improvement of information systems, where there is a reconstruction of a model of care to the mother and child, while respecting their individuality and social and cultural context. [2]

\section{Conclusion}

The SisPrenatal is configured as an important data collection tool for assessing the health care of women in ESF, once the correct handling of data and information associated with the reliable filling of forms and then typing will subsidize the planning of actions in resolute character of health for PHPN indicators, mainly, to guide actions with a local and central character by the managers and health professionals in primary care.

However, it is necessary to correct that the identified barriers in this study such as the inadequate and/or incomplete filling of forms, non-registration of some pregnant women, the lack of training and updating of the professionals who use the system electronically and manually, in addition to the need for greater attention to economically disadvantaged regions, in view of they present the lowest rates of PHPN.

Although, it was obtained from the perspectives brought by this systematic review of research involving the SISPRENATAL that it can be used as an evaluation tool of care during the prenatal and it is also found in some of the articles that the system holds important and indispensable information to the data production process, but it must be modified for its improvement and better performance, as well as, to ensure an improvement in the quality of maternal and perinatal care.

It is also worth to highlight the limitations found to conduct this study because of the few number of publications that address the thematic of SISPRENATAL, being very valuable to the development of future studies that evaluate the use of this system, that in this way, it can be made the necessary modifications to the proper functioning of the system, once it aims to provide data that support decision making by managers and professionals that work in primary health care.

\section{References}

1. Nascimento ER, Paiva MS, Rodrigues QP. Avaliação da cobertura e indicadores do Programa de Humanização do Pré-natal e Nascimento no município de Salvador, Bahia, Brasil. Rev. Bras. Saude Mater. Infant. [Internet]. 2007; [cited 2014 Out 10]; 7(2): 191-197. Available from: http:// www.scielo.br/scielo.php?script=sci $\operatorname{arttext\& pid=\$ 1519-}$ $\underline{38292007000200010 \& \operatorname{lng}=\mathrm{en}}$. 
2. Gangreiro GR, Diógenes MAR, Moura ERF. Atenção PréNatal no Município de Quixadá-CE segundo indicadores de processo do SISPRENATAL. Rev. esc. enferm. USP. [Internet]. 2008; [cited 2014 Jun 10]; 42(1): 105-111. Available from: http://www.scielo.br/scielo.php?script=sci arttext\&pid=S008062342008000100014\&lng=en

3. Corrêa ACP, Arantes RB, Lima AP, Nakagawa JTT. Análise da atenção pré-natal no município de Cuiabá-Mato Grosso segundo dados do Sisprenatal. R. pesq.: cuid. fundam. Online. 5(2): 3740-48, 2013.

4. Brasil. Ministério da Saúde. Secretaria de Atenção à Saúde. Departamento de Ações Programáticas Estratégicas Área Técnica de Saúde da Mulher. Sistema de Monitoramento e Avaliação do Pré-Natal, Parto, Puerpério e Criança - Sisprenatal. [Internet]. 2012; [cited 10 Jun 2014]. Available from: http://portal.saude. sp.gov.br/resources/ses/perfil/gestor/rede-cegonha/sisprenatal videoconferencia.pdf.

5. Brasil. Ministério da Saúde. Manual Técnico Pré-Natal e Puerpério -Atenção Qualificada e Humanizada. Brasília- DF. 2006.

6. Andreucci CB, Cecatti JG. Desempenho de indicadores de processo do Programa de Humanização do Pré-natal e Nascimento no Brasil: uma revisão sistemática. Cad. Saúde Pública [Internet]. 2011; [cited 2014 Out 07]; 27(6): 10531064. Availablefrom: http://www.scielo.br/scielo.php?script=sci arttext\&pid=S0102-311X2011000600003\&lng=en.

7. Almeida CAL, Tanaka OY. Perspectiva das mulheres na avaliação do Programa de Humanização do Pré-Natal e Nascimento. Rev. Saúde Pública [Internet]. 2009; [cited 2014 Out 15]; 43(1): 98104. Disponível em: http://www.scielo.br/scielo.php?script=sci arttext\&pid=S0034-89102009000100013\&lng=pt.

8. Lima A, Correa ACP. A produção de dados para o Sistema de Informação do Pré-Natal em unidades básicas de saúde .Rev. esc. enferm. USP; [Internet]. 2013; [cited 2014 Set 17]; 47(4): 876883. Available from: http://www.scielo.br/scielo.php?script=sci_ arttext\&pid=S0080-62342013000400876\&lng=en

9. Sampaio RFE, Mancini MC. Estudos de revisão sistemática: um guia para síntese criteriosa da evidência científica. Rev. bras. fisioter. 11(1): 83-9; 2007.

10. Pitombeira HCS, Teles LMR, Paiva JSP, Rolim MO, Freitas $L V$, Damasceno AKC. Assistência pré-natal no contexto da estratégia de saúde da família. Rev enferm UFPE on line. 4(1): 615-21; 2010

11. Castro AA. Revisão Sistemática e Meta-análise. [Internet]. 2001; [Acesso 2014 Dez 16]. Available from: http://metodologia.org/ wp-content/uploads/2010/08/meta1.pdf.

12. Andreucci CB, Cecatti JG, Macchetti CE, Sousa $M H$. SISPRENATAL como instrumento de avaliação da qualidade da assistência à gestante. Rev. Saúde Pública. [Internet]. 2011; [cited 2014 Out 07]; 45(5): 854-864. Available from: http://www.scielo.br/scielo.php?script=sci arttext\&pid=S0034$89102011000500006 \& \operatorname{lng}=$ en. Epub Aug 19, 2011.

13. Soares SS, Bento SL, Silva GRF. Diagnóstico da situação de saúde maternoinfantil no município de tanque do Piauí-PI. Rev Bras Promoç Saúde, Fortaleza. 26(1): 79-87; 2013.
14. Serruya SJ, Cecatti JG, Lago TG. O Programa de Humanização no Pré-natal e Nascimento do Ministério da Saúde no Brasil: resultados iniciais. Cad. Saúde Pública [Internet]. 2004; [cited 2014 Out 14]; 20(5): 1281-1289. Available from: http:// www.scielosp.org/scielo.php?script=sci arttext\&pid=S0102311X2004000500022\&lng=en.

15. Serruya SJ, Lago TG, Cecatti JG. Avaliação preliminar do programa de humanização no pré-natal e nascimento no Brasil. Rev. Bras. Ginecol. Obstet. [Internet]. 2004; [cited 2014 Oct 14]; 26(7): 517525. Available from: http://www.scielo.br/scielo.php?script=sci arttext\&pid=S0100-72032004000700003\&lng=en.

16. Nascimento ER, Paiva MS, Rodrigues QP. Avaliação da cobertura e indicadores do Programa de Humanização do Pré-natal e Nascimento no município de Salvador, Bahia, Brasil. Rev. Bras. Saude Mater. Infant. [Internet]. 2007; [cited 2014 Out 07]; 7(2): 191-197. Available from: http:// www.scielo.br/scielo.php?script=sci arttext\&pid=S151938292007000200010\&lng=en.

17. Lima AP, Corrêa ACP. A produção de dados e informações para o SISPRENATAL no nível central de gestão. Ciênc. cuid. saúde [Internet]. 2012; [cited 2014 Out 07]; 11(2): 352-359. Disponível em: http://www.revenf.bvs.br/scielo.php?script=sci arttext\&pid=S1677-38612012000200017\&lng=pt.

\section{Publish in International Archives of Medicine}

International Archives of Medicine is an open access journal publishing articles encompassing all aspects of medical science and clinical practice. IAM is considered a megajournal with independent sections on all areas of medicine. IAM is a really international journal with authors and board members from all around the world. The journal is widely indexed and classified Q1 in category Medicine. 